\title{
Competitive Advantage as a Mediating Variable to the Relationship Between Intellectual Capital and Financial Performance
}

\author{
Hesti Wahyuni*, Erlin Melani, Triesti Candrawati \\ Accounting Department \\ State Polytechnic of Malang \\ Malang, Indonesia \\ *hesti.wahyuni@polinema.ac.id
}

\begin{abstract}
The property and real estate sector is an industrial sector in the Indonesia Stock Exchange which is experiencing rapid growth and pervasive changing. Doing business in this sector must be supported by excellent intellectual capital and competitive strategic to gain sustainable welfare. This study done to explore the direct effect of intellectual capital to financial achievement or the indirect effect through competitive advantage as a strategy tool to gain profit. The population is $\mathbf{4 8}$ companies in property and real estate sector, and 21 companies selected as samples by using purposive sampling method. Hypothesis testing did by using Partial Least Square and all requirement of validity and reliability are fulfilled. As predicted based of the nature and characteristic of this business, intellectual capital has a positively significant effect to financial success both in direct effect. The result of indirect effect through competitive advantage show the positive direction but not significant.
\end{abstract}

Keywords: component, intellectual capital, financial performance, competitive advantage

\section{INTRODUCTION}

The development of urban and demographic aspect in business environment forced property and real estate sector (PRES) become a high level needed of intellectual asset. Facing the tight competition, business actor in this sector must have a premium strategy to lead the business and win the competition. Competition in the PRES need high number of customer values that considered as key to success factors, such as the preference of location, design and product or services development, price, information and networking. All of Those critical success factors can be create by excellent people, excellent business process, excellent innovation and improvement and also excellent relational customer.

These factors were the kind of indicator in intellectual capital variable [1]. To have those kinds of excellent factors an organization should spent their cost to some projects which expected to gain some advantage and win the competition. In this case, management should be aware that the problem is not about how much the cost they spare, but its more about do these cost have significant contribution to the company welfare and sustainability. One of the cost must be spent was to create the capability of human resource and form intangible assets.
To measure the impact intangible asset to the financial achievement is another a big difficulties. Some of those cost is a long-term cost and the result only can be seen in a long period. Those cost that we mention it as intellectual capital will work to win the competition and gain benefit is a blending of human, structure, technology and information to a competitive strategic project. There are two kind of competitive advantage strategies, first is cost leadership and the other is differentiation. Both of those strategy can be achieve by intellectual capital [2]. Normal and status quo mindset of companies did not has improvement program and even radical improvement project so that company cannot lead both in price and innovation.

Intellectual asset is highly needed in PRES sector. Technology, information, human and system is a basic needed to build comfort and health environment, design spectacular building, set low or premium price, and build the strong and close relation to the customers to get valuable information. The investment of intellectual Asset must be controlled by examine the direct effect of intellectual capital to financial performance or it indirect effect through competitive strategy.

The success of intellectual capital in managing an organization is reflected in the achievement of high profitability ratios and high company value. However, the results of empirical testing from several previous studies show varied results. Several studies have successfully confirmed this theory with varying results from each variable. Industrial sector factors also lead to mixed results in measuring intellectual capital and organizational performance relation. Research results in the banking sector also show mixed results.

Clarke et. al. suggested that in the next study added testing variables that mediate or moderate those relationship [3]. Some previous studies have tried to examine the variables that affect the relationship. The results of the research into the relationship of Intellectual Capital and financial performance with competitive strategies as mediators, show that competitive advantage significantly mediates the effect of intellectual capital management to financial performance.

Prior research also show that research development and Intellectual Property rights relate to the firms' financial performance [4]. It also quoted in prior research that 
competitive advantage will build capability in competitiveness and build a bridge to win the competition [5]. There was also founded the incremental of intellectual capital role to create Competitive advantage [5]. Organization culture had significantly influenced intellectual capital, and the intellectual capital had influenced the competitive advantage [5]. Based on these prior research our research question was stated as follow:

H1: Do intellectual asset has positive impact on company profitability ratio in the PRES sector in Indonesian capital market?

H2: Do intellectual asset has positive impact on competitive advantage in the PRES in Indonesian capital market?

H3: Do competitive advantage has positive impact on company profitability ratio in the PRES sector in Indonesian capital market?

H4: Do competitive advantage has positive impact to the impact of Intellectual Capital to company profitability ratio in the PRES sector in Indonesian capital market?

\section{METHODS}

The model of the relationship between intellectual capital and financial performance with Competitive Advantage as a mediating variable is presented in figure 1. This model show the direct effect between intellectual capital performance to finanancial performance, intellectual capital performance to competetitive advantage, and also competitive advantage to financial performance. Beside direct effect there is also drawn indirect effect of intellectual capital performance to financial performance through competitive advantage.

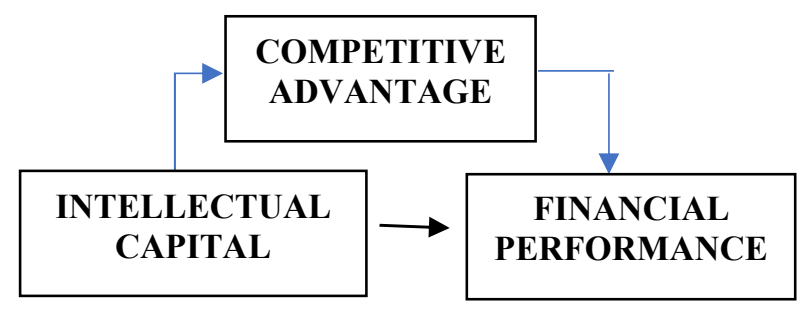

Fig. 1. Research model.

The sample took from the companies as the member of a sector that has highly needed of intellectual capital performance. The sector is PRES sector. The member of this sector has 48 companies as population of this research. The purposive sampling method used to select the data. It is is a non-probability sample with certain criteria with previously known population characteristics. The criteria used in this study are presented in table 1.
TABLE I. SAMPLE SELECTION CRITERIA

\begin{tabular}{|l|l|c|c|}
\hline \multirow{2}{*}{ NO } & \multicolumn{3}{|c|}{ Sample Selection } \\
\cline { 2 - 4 } 1 & \multicolumn{1}{|c|}{ Criteria } & Rejected & Sample \\
\hline \multirow{2}{*}{2} & $\begin{array}{l}\text { Marted in Indonesia Stock } \\
\text { Market }\end{array}$ & 0 & 48 \\
\hline 3 & $\begin{array}{l}\text { Not report the full annual report } \\
\text { in the period 2013 to 2018 }\end{array}$ & 13 & 35 \\
\hline 4 & Suffering Loss & 8 & 28 \\
\hline & Did not use Rupiah as curency & 3 & 24 \\
\hline & Total Sample & & 24 \\
\hline
\end{tabular}

The variables used in this study are divided into three variables namely independent variables, dependent variables, and moderation variables. Independent variable is the variable that is the cause of completion or the impact of the variable received. In this study, the independent variables used in this study are Value Added Intellectual Capital (VAIC) obtained based on added value created by Employee Capital (VACA), Human Capital (VAHU), and Structural Capital (STVA) and Relational Customer (RCVA).

The measurement of intellectual capital in this study uses the concept of added value that was sparked by Pulic. Added value is an indicator used to assess a company's ability to create value (Ulum, 2008). Pulic believes traditional valuation methods are not suitable for measuring performance in the knowledge economy relationship. He therefore supports the use of added value as an indicator to measure performance in 60 knowledge economy relationships. Value Added is calculated as the difference between output and input [6].

The independent variable used is Value Added from intellectual Capital (VAIC). This value is obtained from the sum of added value components of intellectual capital. The component consists of; VACA, VAHU and STVA. Value added is the added value of intellectual capital investment obtained from Output - input. Output is derived from total sales revenue and other income, while Input is all expenses other than employee expenses.

$$
\begin{array}{ll}
\text { VA } & =\text { OUTPUT }- \text { INPUT } \\
\text { VA } & =\text { Value Added } \\
\text { OUTPUT } & =\text { sales and other income } \\
\text { INPUT } & =\text { all expenses except employee expenses) }
\end{array}
$$

$\mathrm{A}$ is a value added indicator (VA) produced by 1 unit of physical capital employed by a company (CE). The VACA ratio shows the comparison between VA and company $\mathrm{CE}$ [7]. It means increase of 1 unit of $\mathrm{CE}$ can increase the return, so the entity maximizes its CE utilization. The VACA calculation formula is:

$$
\begin{aligned}
& \text { VACA = VALUE ADDED / CE } \\
& C E=\text { Capital Employed }=\text { equity }+ \text { net income }
\end{aligned}
$$

Value Added Human Capital (VAHU) VAHU measures the added value of each rupiah used to improve the skills of the workforce. VACA illustrates the benefits of each Human Capital investment rupiah and the added value that accompanies it. Employee costs incurred by companies are usually stated in the salary expense account. Total labor costs are an indicator of company [6]. Note: VAHU (Value Added Human Capital) is measured by the formula: 
Based on outer loading for the variables ROA, STVA, VACA, VAHU known that the indicators have outer loading greater than 0.5 that is equal to 1.0 .

Structural Capital Value Added (STVA) is an indicator that shows the contribution of structural capital (SC) to creating added value (VA) for companies. In this case, the company's $\mathrm{VA}$ is generated by measuring the amount of structural capital (SC) needed to generate 1 rupiah from the VA and is an indication of how successful the SC is in value creation [6]. STVA is the ratio of SC to VA measured by the formula:

\section{STVA = STRUCTURAL CAPITAL / VALUE ADDED}

Structural Capital $=$ Value Added - Human Capital

Relational Customer is the relationship between company and their customer. The closer the relationship the more information the company will get from the customer. this information will be used by the company in making continuous improvements to increase value for customers.

\section{RCVA = RELATIONAL CAPITAL / VALUE ADDED}

\section{Relational Capital $=$ Marketing Cost}

ROA and ROE are used as proxy for dependent variable. ROA is measured by the ratio of the profit ratio of each set of rupiah assets [8]. ROE is the ratio of the profit ratio of each set of rupiah equity [8].

Referring to Suhartati [9], this study uses two dimensions of strategy size, namely asset utilization for cost leadership and efficiency strategies and price premium capability to measure the level of differentiation. Asset utilization efficiency is the ratio of total sales revenues divided by total assets. Meanwhile, price premium capability is the ratio of gross margin divided by total sales revenues. Partial Least Square technique is used for technical analysis that produce conclusions about the direct or indirect effect of independent variable to independent variable.

\section{RESULTS AND DISCUSSION}

Using Partial Least Square technique, it is required two stages of testing model. The first testing model is outer model and the second is outer model. Outer model is a model that specifies the relationship between latent variables and indicators or it can be said that the outer model defines how each indicator relates to its latent variable. VAIC has 4 indicator that consist of VACA, VAHU, STVA and RCVA.

The result from the outer model test RCVA failed to fulfill the requirement of discriminant validity and cross loading test. Innovation and ROE also failed to fulfill the requirement of discriminant validity and cross loading test. It means RCVA must be deleted from the indicator of VAIC. And the conclusion is VAIC has 3 indicator (VACA, VAHU, STVA), while competitive advantage and financial performance each has 1 indicator (Cost leadership and ROA). However, the model is in a formative form, because two of it variables has only 1 as value in data source, so the data to be analyzed are convergently valid.

The following below is the output in the form of Outer Loading value of each variable for the overall model (table 2).
TABLE II. OUTER LOADING

\begin{tabular}{|c|c|c|c|}
\hline \multirow{2}{*}{ Variable } & \multicolumn{3}{|c|}{ Indicator } \\
\hline & $C A$ & $F P$ & VAIC \\
\hline VACA & & & 0.866 \\
\hline CA & 1.000 & & \\
\hline VAHU & - & - & 0.835 \\
\hline ROA & - & 1.000 & - \\
\hline STVA & - & - & 0.900 \\
\hline
\end{tabular}

The value of outer loading test show that all variables value were between the range of 0,5 until 1.0. It means all data are valid on a fixation basis. Thus, all the data can be included in further testing.

Then discriminant validity will be tested by looking Average Variance Extracted root value (AVE) for each construct and comparing it with correlations between constructs. Discriminant validity test is used to see whether an indicator of a particular latent variable is really different from the indicators of other latent variables, so that the indicator is really considered feasible to explain the latent variable.

Discriminant validity testing is done by looking at the average variance extracted (AVE), if the AVE value is greater than 0.5 , then the indicator data is considered to meet convergent validity. It also can be seen by looking at the coefficient value in the cross-loading table, where the highest coefficient value indicates that the indicator indeed represents the observed variable. To find out the results of discriminant validity test in this study, it can be seen from the following and table 3 .

TABLE III. DISCRIMINANT VALIDITY

\begin{tabular}{|l|c|c|c|}
\hline \multirow{2}{*}{ Variable } & \multicolumn{3}{|c|}{ DISCRIMINANT VALIDITY } \\
\cline { 2 - 4 } & $\boldsymbol{C A}$ & $\boldsymbol{F P}$ & $\boldsymbol{V A I C}$ \\
\hline CA & 1.000 & & \\
\hline FP & 0.619 & 1.000 & \\
\hline VAIC & 0.619 & 0.929 & 0.867 \\
\hline
\end{tabular}

Table 3 showed us that all variables have fulfill the requirement of discriminant validity test. The value of discriminant validity of all variable were greater than 0.5 . it means all variable can be used in further testing.

The next step of the outer model is cross loading test. To pass this test, the requirement is the value of cross loading must be between 0.5 until 1.0. It means that the indicators can explain the latent variable in the high level more than 0.5 . 
TABLE IV. CROSS LOADING

\begin{tabular}{|l|c|c|c|}
\hline \multirow{2}{*}{ Variable } & \multicolumn{3}{|c|}{ CROSS LOADING } \\
\cline { 2 - 4 } & $\boldsymbol{C A}$ & $\boldsymbol{F P}$ & $\boldsymbol{V A I C}$ \\
\hline VACA & 0.718 & 0.833 & 0.866 \\
\hline CL & 1.000 & 0.619 & 0.619 \\
\hline VAHU & 0.331 & 0.813 & 0.835 \\
\hline ROA & 0.619 & 1.000 & 0.929 \\
\hline STVA & 0.514 & 0.767 & 0.900 \\
\hline
\end{tabular}

From table 4 can be concluded that all of indicator valid enough to explain the related latent variable. The value that explain this condition is VACA has $86,6 \%$, VAHU has $83,5 \%$ and STVA has $90 \%$ cross loading value to explain VAIC. Other variables are CL has $100 \%$ cross loading value to explain CA and ROA has $92,9 \%$ to explain VAIC. The cross-loading table shows that the correlation of VACA, CL, VAHU, ROA, STVA constructs with the indicator data is higher than the correlation of those indicators with other variables. It shows that latent constructs predict indicators in their blocks better than indicators in other blocks.

The last step of outer model is Reliability testing. This test is done to make sure that all of variables have reliable enough to predict the hypothesis testing model. Construct Reliability (the same as Cronbach alpha measuring construct reliability or latent variables) the value must be above 0.70 which is considered reliable. However, for exploratory research, a moderate reliability of $0.5-0.6$ is sufficient to justify the results of the study (Ferdinand, 2002: 192). The result of this test showed in table 5 .

TABLE V. CONSTRUCT RELIABILITY

\begin{tabular}{|l|l|l|l|l|}
\hline Variable & \multicolumn{4}{|c|}{ CROSS LOADING } \\
\hline & $\begin{array}{c}\text { Cronbach's } \\
\text { Alpha }\end{array}$ & rhoA & $\begin{array}{c}\text { Composite } \\
\text { Reliability }\end{array}$ & AVE \\
\hline CA & 1.000 & 1.000 & 1.000 & 1.000 \\
\hline FP & 1.000 & 1.000 & 1.000 & 1.000 \\
\hline VAIC & 0.836 & 0.847 & 0.901 & 0.752 \\
\hline
\end{tabular}

Table 5 presented that Composite reliability is good if the value is above 0.70 . Thus, it can be said that the indicators of CA, FP, VAIC, really reinforce each other's latent variables or really able to measure their latent variables. So, the model in this study has met the composite reliability. Construct reliability based on Cronbach's alpha is good if the value is above 0.70 . Based on the above table, all observed variables Cronbach's alpha are above 0.70. It means the model in this study has fulfilled Construct reliability requirement.

The second step of PLS technique is inner model testing. Inner model testing consist of 3 testing. Firstly is R Square testing, secondly is direct effect (path coefficient and $p$ value) and the third is indirect effect (path coefficient and $\mathrm{p}$ value). The result of these tests presented in table 6 , table 7 and table 8 below.

Inner model or structural model testing consist of the measurement of R Square value and the value of hypothesis testing result. R-square (R2) value for dependent construct reflects the predictive power of the whole model with the limitation on the R-square value greater than 0.10 or greater than 10 percent (or goodness-fit of the model). Based on data processing by PLS, the coefficient of determination (R-square) is produced. The result shows in table 6 .

TABLE VI. R SQUARE

\begin{tabular}{|l|l|l|}
\hline Variable & \multicolumn{2}{|c|}{ R SQUARE } \\
\hline & \multicolumn{1}{|c|}{ R Square } & Adj $\boldsymbol{R}$ Square \\
\hline CA & 0.383 & 0.378 \\
\hline FP & 0.866 & 0.864 \\
\hline
\end{tabular}

From table 6 known that the R-square for the CA variable as a mediating variable is 0.383 , means that the $\mathrm{CA}$ is influenced by VAIC of $26.0 \%$. R-square value for FP variable is 0.864 , it shows that FP is influenced by CA and VAIC of $86.4 \%$.

Hypothesis testing and the direct relationship between variables can be seen from the results of the path coefficient on the model, here are the results of the path coefficient on the inner model. The relationship stated in table 7.

TABLE VII. PATH COEFFICIENT

\begin{tabular}{|l|l|l|l|l|}
\hline \multicolumn{1}{|c|}{ Variable } & \multicolumn{4}{|c|}{ PATH COEFICIENT } \\
\hline & Mean & \multicolumn{1}{c|}{$($ STDEV $)$} & T Stat & P Values \\
\hline CA -> FP & 0.077 & 0.053 & 1.354 & 0.176 \\
\hline VAIC - > CA & 0.623 & 0.063 & 9.817 & 0.000 \\
\hline VAIC -> FP & 0.880 & 0.039 & 22.785 & 0.000 \\
\hline
\end{tabular}

Concluded from table 7 , direct effect from Intellectual capital to financial performance and Intellectual Capital to Competitive Advantage are positively significant, and the direct effect from competitive Advantage to financial performance is not significant. Significant effect proved by the value of $T$ statistic is higher than 2 and $P$ value is lower than 0.05. It means Intellectual Capital directly affect both competitive Advantage and financial performance and the vice versa competitive advantage has no significant effect to financial performance.

The indirect effect explained by the relation between Intellectual capital and Financial Performance through Competitive Advantage. Significant effect is detected with the t- stat value that greater than 2. Another way to detect significant effect is p-value must be lower than 0.05 . The result of indirect effect in this research showed in table 8 .

TABLE VIII. TOTAL INDIRECT EFFECT

\begin{tabular}{|l|l|l|l|l|}
\hline \multicolumn{1}{|c|}{ Variable } & \multicolumn{4}{|c|}{ PATH COEFICIENT } \\
\hline CA -> FP & Mean & (STDEV) & T Stat & P Values \\
\hline VAIC -> CA & & & & \\
\hline VAIC -> FP & 0.049 & 0.035 & 1.269 & 0.205 \\
\hline
\end{tabular}

Table 8 draw the result of this test. The number of $\mathrm{T}$ statistic in table 8 is 1.269 means lower than 2 and the $P$ value number 0.205 is greater than 0.05 indicate that Competitive Advantage has no significant effect to this relation.

Further discussion of intellectual capital in PRES sector found that good Intellectual capital management will give a positive effect to good and effective asset utilization. Effective 
asset utilization means there were an incremental profit in every resources spent. To achieve the incremental profit only can be realized by intellectual capital that consist of smart people, smart technology, qualified information dan efficient procedure and system. This mess of these capital will create excellent financial performance.

Some research found that IC and performance has interaction effects in banking industry. Prior researcher also agree that intellectual property rights has significant relation to the firms' financial performance [4]. Intellectual capital role to create firms' financial performance is a predictor in the emerging market context [10]. It is also found that in banks sector, financial performance relation with human capital efficiency than physical capital efficiency and is higher than structural capital efficiency [11]. The more cost spent in intellectual capital should be continued by customer value creation and positive impact to financial aspect. There are two ways to create financial performance. Firstly, Investment in intellectual asset will increase the level of productivity, effectiveness and efficient of asset utilization so the company will produce their output in low cost. Second, intellectual capital used in research and development program to create new customer value of company products or services. So, it can be concluded that intellectual capital has positive effect to financial performance and the result of this research is at the same manner.

This study also successfully prove that intellectual has significant effect to competitive advantage. Competitive advantage is such a sophisticated engine in a company that only can be operated by well managed intellectual capital. Some prior research study found the significant effect of IC to competitive advantage, but contrary other research showed the vice versa. We also should pay more attention to IC management as the trigger to increase competitiveness [12]. IC component (relational capital, structural capital, and human capital) grant relative contribution to competitive advantage [1] it also created from organization culture [13]. Significant effects of the three Intellectual Capital components yield competitive advantage, human-development capital (HDC) has a highest impact, than structural capital (SC) and last is relational capital [7].

Some issues in the relationship of intellectual capital and competitive advantage is; first issue is many business doubt to spent the cost of intellectual asset to run research and development program. The second issues is companies has intellectual capital investment but failed to create competitive advantage because the lack of control or bad management in intellectual capital. So that the conclusion is good control and management of intellectual capital will create the competitive advantage.

Invested resources and the human value-added resources and maintained customer relationships represent competitive advantages has significant effect to performance was used to explain corporate value $[14,15]$. It is also found that research and development relate to the firms' financial performance [3]. The results of Cheng [1] suggested the consideration of the innovative capacity and process reformation, and through VAHU, firms can improve their company's performance.
This research finding is failed to prove this hypothesis. The explanation of this result related to the Cost Leadership as indicator used in this competitive advantage variable. As stated in Dixon and Abdullah [16,17], the critical success factor of real estate sector are; location, positive cash flow, and well manage financial analysis. None of them said about cost leadership strategy. So, it can be conclude that cost leadership as competitive advantage strategy is failed to create financial performance.

Many suggestions from prior study stated that in the next study added testing variables that mediate or moderate the relation between Intellectual Capital and financial performance [3]. The results show that competitive advantage significantly mediates the causative of intellectual capital management to financial performance [3]. As stated before, we know that intellectual capital will create financial return if it well managed and controlled. The role of competitive advantage is to direct the intellectual management to achieve some unique differences or cost efficient as a result of learning process and continuous improvement, such as a guidance and trigger for intellectual capital to create financial benefit.

From a financial measurement view, first, the innovative capacity and efficient operating processes are used as proxy variables of invested resources. Second, the human valueadded resources and maintained customer relationships represent competitive advantages; and finally, performance was used to explain corporate value [1]. Additionally, this paper uses the IC perspective to describe the value-creating process [12]. Competitive Advantage has significant mediating the intellectual capital and financial performance association in micro finance industry [2]. Business relationships include both collaborative and competitive dimensions. Collaborating competitors is interesting to be tested in the next research as competitive elements surely are present also in other types of business relationships.

This research failed to prove the mediating effect of competitive advantage. The matter is cost leadership is failed to be a critical success factor of real estate sector. Because in this sector location and building esthetic is the key of the customer value, although the price is high. The intangible assets of a firm such as people, image and intellectual property are especially important for achieving competitive advantage because of the fact that they are hard to imitate [8]. Significant mediately effect of organizational ambidexterity also found in this case. Intellectual Capital helps firms attaining competitiveness [7].

\section{CONCLUSION}

It concludes that intellectual capital is an important asset because it has positively impact to Competitive Advantage and financial performance. That asset must be owned by all company to implement competitive strategy and create profit. The role of intellectual capital. Intellectual Capital Also directly affect the creation of financial performance. This study also find the prove that Competitive advantage has significant effect to financial performance

In mediating effect of competitive advantage to the relationship between intellectual capital and financial performance, cost leadership failed to confirm the prior study. 
[5] M. Igielski, "The role of intellectual capital in building a competitive advantage for companies from the Baltic Sea Region in the transport, shipping and logistic industry (TSL)". In SHS Web of Conferences Vol. 57, pp. 01-15). EDP Sciences. (2018).

Cost leadership strategy has already exist but the effect is not significantly mediating the relationship. It means more effort is needed to be developed to maximize the contribution intellectual capital and competitive advantage to increase the entity profit and value. The improvement of competitive advantage strategy need to be defined carefully. The right type of alternative strategy and the key success factor of each business must be known as well so that the positive relation with financial performance will be achieve.

Competitive advantage plays a role in facilitating creative innovation or producing quality products at competitive prices. A competitive strategy is a tool in creating competitive advantage. Competitive advantage consists of cost leadership or innovation leadership or a combination of both strategy. The implementation of competitive strategy will become a trigger to customer value creation process, continuous improvement, increased organizational innovation will become a culture that strengthens the organization's position in creating competitive advantage and winning competition.

The suggestion for further research is used another indicator to measure Competitive advantage. The proper indicator to the competitive advantage strategy must be related to the key success factor of the business, so it will lead to valuable measurement.

\section{REFERENCES}

[1] M. Y. Cheng, J. Y. Lin, T. Y.Hsiao, and T. W. Lin,. "Invested resource, competitive intellectual capital, and corporate performance," Journal of Intellectual Capital, vol. 11(4), pp. 433-450, 2010.

[2] N. Kamukama, , A.Ahiauzu, and J. M. Ntayi,. "Competitive advantage: mediator of intellectual capital and performance". Journal of intellectual capital, vol 12(1), pp. 152-164, 2011

[3] M. Clarke, D. Seng, and R.H. Whiting. "Intellectual capital and firm performance in Australia." Journal of Intellectual Capital, vol. 12(4), pp. 505-530. 2011.

[4] W.S. Chang, "Are R\&D and intellectual property rights related to the firms' financial performance? The perspectives on intellectual capital," International Journal of Technology, Policy and Management, vol. 13(3), pp. 245-260, 2013.
[6] A. Pulic, VAICTM journal of technology management, 20(5-8), 702-714. Ff. 2000.

[7] M. Shujaat, N. Naghavi, and F. Mubarak, Impact of supplier relational capital on supply chain performance in Pakistani textile industry. Asian Econ. Financ. Rev, 9(3), 318-328. 2019.

[8] M. Solitander and A. Tidström, Competitive flows of intellectual capital in value creating networks. Journal of Intellectual Capital, 11(1), 23-38. 2010 .

[9] T. Suhartati and H. Rosietta, Pengaruh Strategi Bersaing Terhadap Hubungan Antara Supply Chain Management Dan Kinerja. Universitas Indonesia. Simposium Nasional Akuntansi XV. 2012.

[10] T. Tripathy, L. Gil-Alana, and D. Sahoo. "Effect of Intellectual Capital on Firms ${ }^{-}$Competitive Advantage Condition: An Empirical Investigation in India." Review of Economics \& Finance, vol. 8, pp. 6178. 2017.

[11] M. Joshi, D. Cahill, J. Sidhu, and M. Kansal, Intellectual capital and financial performance: an evaluation of the Australian financial sector. Journal of intellectual capital, 14(2), 264-285. 2013.

[12] G. Secundo, J. Dumay, G. Schiuma, and G. Passiante, Managing intellectual capital through a collective intelligence approach: an integrated framework for universities. Journal of Intellectual Capital, 17(2), 298-319. 2016.

[13] D. Indiyati, "The role of organisational culture, intellectual capital and competitive advantage in supporting the government policies in education." International Journal of Economic Policy in Emerging Economies, vol. 11(1-2), pp. 68-82. 2018.

[14] N. Kamukama and T. Sulait, Intellectual capital and competitive advantage in Uganda's microfinance industry. African Journal of Economic and Management Studies, 8(4), 498-514. 2017.

[15] P. Puntillo, Intellectual capital and business performance. Evidence from Italian banking industry. Electronic Journal of Corporate Finance, 4(12), 97-115. 2009

[16] T. Dixon, G. Pottinger, and A. Jordan, Lessons from the private finance initiative in the UK: Benefits, problems and critical success factors. Journal of Property Investment \& Finance, 23(5), 412-423. 2005.

[17] S. Abdullah, M.N.M. Nah, and A.A. Razak, Real Estate Management in Malaysian Public Schools: Determination of Success Factors. Real Estate Management and Valuation, 23(2), 52-6. 2015. 